\title{
A PROSPECTIVE MODIFICATION STRUCTURE: THE EFFECT OF LIPOPHILIC AND ELECTRONIC PROPERTIES OF $N$-(PHENYLCARBAMOTHYOIL)BENZAMIDE DERIVATIVES ON CYTOTOXIC ACTIVITY BY IN SILICO AND IN VITRO ASSAY WITH T47D CELLS
}

\author{
D. Kesuma ${ }^{1}$, A.L. Nasyanka ${ }^{2, *}$, M. Rudyanto ${ }^{3}$, Siswandono ${ }^{3}$, B.T. Purwanto ${ }^{3}$ \\ and I.G.A. Sumartha ${ }^{1}$ \\ ${ }^{1}$ Department of Pharmaceutical Chemistry, University of Surabaya, Surabaya-60293, \\ (East Java) Indonesia \\ ${ }^{2}$ Departement of Pharmacy, University of Muhammadiyah Gresik, Gresik-61111, \\ (East Java) Indonesia \\ ${ }^{3}$ Department of Medicinal Chemistry, University of Airlangga, Surabaya-60286, \\ (East Java) Indonesia \\ *E-mail: anindilupita@umg.ac.id
}

\begin{abstract}
Topliss aromatic modification structure considers two important properties, lipophilic and electronic. This study is to prove lipophilic and electronic properties effect of an anticancer lead compound $N$-(phenylcarbamothyoil) benzamide using in silico and in vitro method. We used in silico method that docked two derivatives (4-nitro and 4-methyl moieties) in the sirtuin-1 receptor (PDB ID: 4i5i) using autodock tools. They were screened for cytotoxic activity on T47D cells with MTT Method. The result showed that there were different activities in docking prediction and cytotoxic activity on T47D. 4-Nitro PCTB had more increased activity than 4-methyl.It was implied that electronic activity is more affecting cytotoxic activity than lipophilic properties.

Keywords: Lipophilic Effect, Electronic Effect, N-(phenylcarbamothyoil)Benzamide, T47D Cell, In-silico

(C) RASĀYAN. All rights reserved
\end{abstract}

\section{INTRODUCTION}

Since a long ago, modification of drug structure is one of the promising methods to find new active drug compounds. A lead compound must be developed first with this method ${ }^{1}$. Lead compound structure modification varies, but changing its physical and chemical properties by adding substituent makes it more active as a drug ${ }^{2}$. Every substituent has its effect on pharmacokinetics and pharmacodynamics ${ }^{3}$.

Topliss proposed guidelines for structural modification of non-mathematical, non-statistical and noncomputerized parent compounds using the basic principles of the structural relationship approach and the activities of the Hansch model ${ }^{4}$. The structural modification of Topliss method includes groups that have certain lipophilic, electronic, and steric properties at certain positions in the lead compound structure, which are predicted to produce compounds with higher, equal, or lower activity than the lead compound, and lastly to find the most profitable synthesis pathway ${ }^{5}$.

In this study, we had structural modification of two $N$-(phenylcarbamothyoil)benzamide (PCTB) derivatives based on their lipophilic and electronic effects. $N$-(phenylcarbamothyoil)benzamide is known as cytotoxic thiourea derivatives compound that has better activity than hydroxyurea ${ }^{6}$. Tenovin 1 is a name given to thiourea derivatives 1-(4 acetamidophenil)3-4-tertbuthylbenzoyl) thiourea. It has been recognized to possess anticancer activity through synthesis and evaluation as suggested by another research. Also, it 
RASĀYAN J. Chem.

Vol. 13 | No. 3 |1914-1918| July - September | 2020

owns a reputation to elevate the levels of $\mathrm{p} 53$ protein in vitro (which inhibits SIRT1) ${ }^{7}$. Moreover, $\mathrm{N}-($ allylcarbamathioyl) benzamyde is also evident to have activity as breast anticancer (T47D cells) ${ }^{8}$.

Aromatic ring modification in Topliss method only considers two properties, lipophilic and electronic 9 Lipophilic properties affect drug penetration through the cell membrane and increase the amount of drug bound into a receptor, which increases its activity. While electronic properties have a role in drug solubility at the distribution and interaction of drug-receptor ${ }^{10}$.

To prove lipophilic and electronic effects of $N$-(phenylcarbamothyoil)benzamide on cytotoxic activity, we used 4-Nitro and 4-Methyl to represent each effect, respectively. Nitro has strong electronic effect $(\sigma=$ 0.78 ) and methyl has strong lipophilic effect $(\pi=0.56)^{11}$. Later on, we used two different cytotoxic activity methods on T47D, in silico and in vitro, to imply the effect on $N$-(phenylcarbamothyoil) benzamide.

\section{EXPERIMENTAL}

\section{Molecular Modeling}

The chemical structures were sketched using Marvin sketch software (Version 19.17.0) and converted to 3D Form for docking studies using Avogadro (Version 1.2.0). Merk Molecular Force Field (MMFF94), which optimizes the geometry's structures, was also utilized with Avogadro principles saved in .mol2.

\section{In-silico Cytotoxic Activity Prediction}

Molecular modeling of N-(phenylcarbamothyoil) benzamide was conducted to predict the activity. A molecular docking method with Histon deacetylase SIRT1 (ID=4i5i) was performed by utilizing Autodock software. Retrieved from PDB bank server was the Sirtuin-1 (SIRT1) enzyme. As to provide protein molecule ligand, AutoDock Tool (version 1.5.6) was applied. Based on experimental conducts, grid box values were acquired to assign the perfect grid parameters in the ligand.

\section{Synthesis}

Synthesis had been done by reacting $0.03 \mathrm{~mol} \mathrm{~N}$-phenylthiourea, $0.025 \mathrm{~mol}$ triethylamine, and $0.025 \mathrm{~mol}$ 4-Nitro/4-Methylbenzoyl chloride solution in tetrahydrofuran, followed by refluxing and stirring the mixture placed in a water bath and TLC, once per hour. Just as any spot appeared, the reaction was halted. Afterward, THF evaporation on the rotary was continued with recrystallization. The compound structure identification was conducted based on infrared spectroscopy, ${ }^{1} \mathrm{H}-\mathrm{NMR},{ }^{13} \mathrm{C}-\mathrm{NMR}$, and HRMS result. ${ }^{12-14}$

\section{Cytotoxic Activity on T47D Cell}

By employing T47D, the breast cancer cells, anticancer activity is conducted in vitro. To produce 50.000 $\mu \mathrm{g} / \mathrm{mL}$ concentration, the test compound (5 mg) was fused in DMSO (100ul). To derive a group of standard working solution, the mother liquor was steadily diluted both by adding RPMI culture medium for T47D cells and M199 for Vero cells ${ }^{15}$.In a 96-wells microplate, a culture of T47D cancer cell was set in the contour of cell suspension. It was employed with 10,000 cells / pitting in terms of density for this study. For media control, the plate was added with empty wells followed by $\mathrm{CO}_{2} 5 \%$ incubator, left for 24 hours. After the incubation period was over, the plate was taken away. With 180 degrees of reversion, the media was removed. Every single well was rinsed using $100 \mu \mathrm{l}$ PBS. Afterward, the plate was rotated 180 degrees and PBS was discarded. Set in microplate wells were the concentration of a standard working solution $(100 \mu \mathrm{L})$, positive control and solvent control. Each of the concentrations was then duplicated three times. As for media control, it was derived from the sums containing no T47D cancer cells, incubated 24 hours with $5 \% \mathrm{CO}_{2}$ incubator at $37^{\circ}$. Both the plate and the incubator were then discarded after that 24 hours. Added to every well was $0.5 \mathrm{mg} / \mathrm{ml}$ of MTT up to $100 \mu \mathrm{L} /$ well, incubated for three hours ${ }^{16}$. After the incubation and the microplate were removed, terminating the reaction was proceeded by putting $100 \mu \mathrm{L}$ SDS $10 \%$ in $0.1 \mathrm{~N} \mathrm{HCl}$ inside the hole. Covered with aluminum paper, the microplate was nurtured with $5 \% \mathrm{CO}_{2}$ in an incubator for 24 hours and inserted in Elisa Reader at $\pi=595 \mathrm{~nm}$. $\mathrm{IC}_{50}$ values were obtained using probit analysis out of the test compound. ${ }^{17}$

\section{In-silico Cytotoxic Activity Prediction}

\section{RESULTS AND DISCUSSION}

In silico study, the result showed that both 4- $\mathrm{NO}_{2}-\mathrm{PCTB}$ and 4- $\mathrm{CH}_{3}-\mathrm{PCTB}$ has Binding Score (BS) lower than hydroxyurea (HU) as reference. Hence, it was predicted that they have better activity in sirtuin-1 
RASĀYAN J. Chem.

Vol. 13 | No. 3 |1914-1918| July - September | 2020

receptor. According to Table-1, 4- $\mathrm{NO}_{2}-\mathrm{PCTB}(-9.69 \mathrm{kcal} / \mathrm{mol})$ has BS lower than other derivatives, 4- $\mathrm{CH}_{3}-$ PCTB $(-8.34 \mathrm{kcal} / \mathrm{mol})$. It inferred that $4-\mathrm{NO}_{2}$ substituent donates a strong and stable ligand-protein bond than $4-\mathrm{CH}_{3}$. Nitro substituent in para position has a stronger electronic effect compared to its lipophilic effect $(\sigma=0.78)$, while methyl in para position had stronger lipophilic effect than its electronic effect in QSAR parameter $(\pi=0.56)^{18}$. This was following previous research which states the electronic properties play a role in the stability of interactions between drugs and receptors. ${ }^{19}$

Table-1: Binding Score and Interaction Binding of 4- $\mathrm{CH}_{3}-\mathrm{PCTB}, 4-\mathrm{NO}_{2}-\mathrm{PCTB}$, and Hydroxyurea

\begin{tabular}{|c|c|c|}
\hline Substituent & Binding Score $(\mathrm{Kcal} / \mathrm{mol})$ & Interaction Binding \\
\hline $4-\mathrm{CH}_{3}-\mathrm{PCTB}$ & -8.34 & $\begin{array}{l}\text { Interactions } \\
\text { Conventional Hydrogen Bond } \\
\text { Pi-Donor Hydrogen Bond } \\
\text { Pi-Sigma }\end{array}$ \\
\hline $4-\mathrm{NO}_{2}-\mathrm{PCTB}$ & -9.69 & $\begin{array}{l}\text { ILE } \\
\text { Interactions } \\
\text { Conventional Hydrogen Bond } \\
\text { Pi-Donor Hydrogen Bond } \\
\text { Pi-Sigma }\end{array}$ \\
\hline $\mathrm{HU}$ & -2.26 & $\begin{array}{l}\text { A: } \\
\text { Interactions } \\
\text { van der waals } \\
\text { water Hydrogen Bond }\end{array}$ \\
\hline
\end{tabular}


RASĀYAN J. Chem.

Vol. 13 | No. 3 |1914-1918| July - September | 2020

Another important result from Table-1 was the interaction of 4- $\mathrm{NO}_{2}-\mathrm{PCTB}$ and 4- $\mathrm{CH}_{3}-\mathrm{PCTB}$ with sirtuin1. It showed that lower BS is affected by the quantity and the quality of occurring bond ${ }^{20}$. In 4-NO $-\mathrm{NO}_{2}-\mathrm{PCTB}$ strengthened with 13 bonds, there are 6 hydrogen conventional bonds (GLNA345 (two bond in receptor), LYSA44, SERA422, HISA363, ASNA346), 3 pi-alkyl bonds (ILEA411, ALAA262, VALA445), 1 pi-pi T-shaped bond (PHE A297), 1 pi-sulfur bond (PHEA273), 1 pi-sigma bond (ILEA347), and 1 pi donor hydrogen bond (GLNA345). However, 4- $\mathrm{CH}_{3}-\mathrm{PCTB}$ has higher BS because it was strengthened with 8 bonds; They are 2 hydrogen conventional bonds (GLNA345, HIS A363), 1 pi donor hydrogen bond (GLN A345), 1 pi sigma bond(ILE A347), 1 pi sulfur bond(PHEA273), 1 pi-pi T shaped bond (PHEA297), and 2 $p i$-alkyl bonds (ILEA411 and ALA A262). Therefore, in silico study result predicted that more bonds in ligand-receptor interaction create a stronger bond with lower binding score ${ }^{21}$.

\section{Synthesis}

The synthesis began with R-benzoyl Chloride $\left(\mathrm{R}=4-\mathrm{CH}_{3}\right.$ and 4- $\left.\mathrm{NO}_{2}\right)$ combined with $\mathrm{N}$-phenylthiourea $-\mathrm{a}$ yellow light crystals luster and insoluble in water - in one step, from which the 4- $\mathrm{CH}_{3}-\mathrm{PCTB}$ and $4-\mathrm{NO}_{2}-$ PCTB compounds were derived. The structure identification of the synthesized compounds was conducted by IR, H NMR, C NMR and HRMS spectroscopy as mentioned in the following details:

\section{$\mathrm{N}$-(Phenylcarbamothioyl)-4-methyl benzamide}

White crystal, yield 77\%, m.p. $115-116^{\circ} \mathrm{C} .{ }^{1} \mathrm{H}$ NMR (DMSO- $d_{6}, 500 \mathrm{MHz}$ ). $\delta 2.45$ (s, 3H,CH ); $\delta 7.29$ (t, $J=7.8 \mathrm{~Hz}, 1 \mathrm{H}, \mathrm{Ar}-\mathrm{H}) ; \delta 7.33(\mathrm{~d}, J=8.1 \mathrm{~Hz}, 2 \mathrm{H}, \mathrm{Ar}-\mathrm{H}) ; \delta 7.42(\mathrm{t}, J=7.8 \mathrm{~Hz}, 2 \mathrm{H}, \mathrm{Ar}-\mathrm{H}) ; \delta 7.71(\mathrm{~d}, J=7.8 \mathrm{~Hz}$, $2 \mathrm{H}, \mathrm{Ar}-\mathrm{H}) ; \delta 7.79$ (d, $J=8.1 \mathrm{~Hz}, 2 \mathrm{H}, \mathrm{Ar}-\mathrm{H}) ; \delta 9.10$ (s, $1 \mathrm{H}, \mathrm{O}=\mathrm{C}-\mathrm{NH}-\mathrm{C}=\mathrm{S}) ; \delta 12.64$ (s, $1 \mathrm{H}, \mathrm{S}=\mathrm{C}-\mathrm{NH}-\mathrm{Ar}) .{ }^{13} \mathrm{C}$ NMR (DMSO- $\left.d_{6}, 125 \mathrm{MHz}\right) . \delta 21.8\left(1 \mathrm{C}, \mathrm{CH}_{3}\right) ; \delta 124.3$ (2C, $\left.\mathrm{Ar}\right) ; \delta 127.0(2 \mathrm{C}, \mathrm{Ar}) ; \delta 127.7$ (1C, Ar); 128.8 (2C, Ar); $\delta 129.0(2 \mathrm{C}, \mathrm{Ar}) ; 130.0(1 \mathrm{C}, \mathrm{Ar}) ; \delta 137.8(1 \mathrm{C}, \mathrm{Ar}) ; \delta 145.0(1 \mathrm{C}, \mathrm{Ar}) ; \delta 167.0(1 \mathrm{C}, \mathrm{C}=\mathrm{O}) ; \delta$ $178.6(1 \mathrm{C}, \mathrm{C}=\mathrm{S})$. IR (KBr), $v$ maks $\left(\mathrm{cm}^{-1}\right): 1672(\mathrm{C}=\mathrm{O}$ amide $) ; 1603$ dan $1496(\mathrm{C}=\mathrm{C}$ Aromatic); 3313 and 1603 (NH stretch sec. amides); 1075 dan $807(\mathrm{C}=\mathrm{S})$. HRMS $(\mathrm{m} / \mathrm{z}) \mathrm{C}_{15} \mathrm{H}_{13} \mathrm{~N}_{2} \mathrm{OS}:(\mathrm{M}-\mathrm{H})^{-}=269.0757$ and Calc. Mass $=269.0749$.

\section{$\mathrm{N}$-(Phenylcarbamothioyl)-4-nitro benzamide}

Yellow crystal, yield $65 \%$, m.p. $129-1300^{\circ} \mathrm{C} .{ }^{1} \mathrm{H}$ NMR (DMSO- $\left.d_{6}, 500 \mathrm{MHz}\right) \delta 6.94(\mathrm{t}, J=8.0,1 \mathrm{H}, \mathrm{Ar}-\mathrm{H})$; $\delta 7.12(\mathrm{t}, J=8.0 \mathrm{~Hz}, 2 \mathrm{H}, \mathrm{Ar}-\mathrm{H}) ; \delta 7.37(\mathrm{~d}, J=8.0 \mathrm{~Hz}, 2 \mathrm{H}, \mathrm{Ar}-\mathrm{H}) ; \delta 7.76(\mathrm{~d}, J=8.0 \mathrm{~Hz}, 2 \mathrm{H}, \mathrm{Ar}-\mathrm{H}) ; \delta 8.35$ (d, $J=8.0 \mathrm{~Hz}, 2 \mathrm{H}, \mathrm{Ar}-\mathrm{H}) ; \delta 9.56$ (s, $1 \mathrm{H}, \mathrm{O}=\mathrm{C}-\mathrm{NH}-\mathrm{C}=\mathrm{S}) ; \delta 10.54$ (s, $1 \mathrm{H}, \mathrm{S}=\mathrm{C}-\mathrm{NH}-\mathrm{Ar}) .{ }^{13} \mathrm{C}$ NMR (DMSO- $d_{6}$, $125 \mathrm{MHz}) \delta 118.7$ (2C, Ar); $\delta 121.1$ (2C, Ar); $\delta 122.4$ (1C, Ar); $\delta 122.5$ (2C, Ar); $\delta 124.1$ (2C, Ar); $\delta 124.9$ (1C, Ar); $\delta 129.6(1 \mathrm{C}, \mathrm{Ar}) ; \delta 140.3$ (1C, Ar); $\delta 160.3(1 \mathrm{C}, \mathrm{C}=\mathrm{O}) ; \delta 171.2(1 \mathrm{C}, \mathrm{C}=\mathrm{S})$. IR (KBr), $v$ maks( $\mathrm{cm}^{-}$ $\left.{ }^{1}\right)$ : 1651 ( $\mathrm{C}=\mathrm{O}$ amide); 1635 and $1497(\mathrm{C}=\mathrm{C}$ aromatic); 3322 and 1635 (NH stretch sec amides); 1104 and $830(\mathrm{C}=\mathrm{S})$. HRMS $(m / z) \mathrm{C}_{14} \mathrm{H}_{12} \mathrm{~N}_{3} \mathrm{O}_{3} \mathrm{~S}:(\mathrm{M}+\mathrm{H})^{+}=302.0536$ and Calc. Mass $=302.0534$.

\section{Cytotoxic Activity}

In vitro MTT Assay in T47D result showed the same activity to in silico study. $\mathrm{IC}_{50}$ 4- $\mathrm{NO}_{2}-\mathrm{PCTB}(0.12$ $\mathrm{mM}$ ) was lower than 4- $\mathrm{CH}_{3}-\mathrm{PCTB}(1.08 \mathrm{mM})$. In other words, 4- $\mathrm{NO}_{2}-\mathrm{PCTB}$ is more potent than 4- $\mathrm{CH}_{3}-$ PCTB as an anticancer agent in T47D. The effect of the electron withdrawal group is stronger than the electron contributor group.

Both of 4- $\mathrm{NO}_{2}-\mathrm{PCTB}$ and 4- $\mathrm{CH}_{3}-\mathrm{PCTB}$ had better activity than hydroxyurea as reference. They also had cancer cell-targeted mechanisms from the cytotoxic assay in Vero cell as a normal cell. The result was both of them toxic in T47D cell but not in vero cell. Thus, they are worthy to develop as an anticancer agent in T47D cells with mechanism prediction of sirtuin-1 receptor inhibition.

Table-2: RS, IC $_{50}$ T47D, and Vero Cells Values of Test Compounds and Reference Compounds

\begin{tabular}{c|c|c|c}
\hline Compounds & $\mathrm{RS}(\mathrm{Kcal} / \mathrm{mol})$ & $\mathrm{IC}_{50} \mathrm{~T} 47 \mathrm{D}$ Cells $(\mathrm{mM})$ & $\mathrm{IC}_{50}$ Vero Cells $(\mathrm{mM})$ \\
\hline $4-\mathrm{CH}_{3}$-PCTB & -8.34 & $1.08 \pm 0.013$ & $53.58 \pm 0.004$ \\
\hline $4-\mathrm{NO}_{2}$-PCTB & -9.69 & $0.12 \pm 0.014$ & $65.63 \pm 0.003$ \\
\hline $\mathrm{HU}$ & -2.26 & $4.58 \pm 0.019$ & $369.88 \pm 0.015$ \\
\hline
\end{tabular}


RASĀYAN J. Chem.

Vol. 13 | No. 3 |1914-1918| July - September | 2020

To develop another derivative of $N$-(phenylcarbamothyoil)benzamide, structural modification in the aromatic compound must be considered in the selection of moiety with another electron withdrawal group with a higher electronic parameter $\sigma(+)$ but slightly higher lipophilic parameter $(\pi)$. It should still use the Lipinski rule because the activity is affected by the physicochemical characteristic of the moiety. Furthermore, in silico study in both derivatives supports invitro cytotoxic activity assay. Hence, in silico study can be used as activity prediction before synthesis and in vitro study.

\section{CONCLUSION}

In $\mathrm{N}$-(phenylcarbamothyoil)benzamide derivatives compounds, nitro substituent has a stronger cytotoxic effect than methyl. It can be concluded that the $\mathrm{N}$-(phenylcarbamothyoil) benzamide derivatives compound has a stronger electronic effect than the lipophilic effect. This can be used to develop more anticancer agent compounds from this lead compound.

\section{ACKNOWLEDGEMENT}

Funding support for this study was from Indonesia's Doctorate General of Resources for Science, Technology and Higher Education under the Ministry of Research, Technology and Higher Education (KEMENRISTEK DIKTI) following the scholarship funding scheme for $\mathrm{PhD}$ program at University of Airlangga, Surabaya Indonesia.

\section{REFERENCES}

1. J.M. Beale and J.H. Block, Wilson and Gisvolds Textbook of Organic Medicinal and Pharmaceutical Chemistry $12^{\text {th }}$ ed, Lippincott Williams \& Wilkins, Philadelphia, (2011)

2. S. Siswandono, Pengembangan Obat Baru, Airlangga University Press, Surabaya, (2014)

3. G. Thomas, Medicinal Chemistry $2^{\text {nd }} e d$, John Wiley \& Sons, New York, (2007)

4. J.G. Topliss, Journal of Medicinal Chemistry, 15(10), 1006(1972), DOI:10.1021/jm00280a002

5. G.L. Patrick, An Introduction to Medicinal Chemistry $5^{\text {th }} e d$, Oxford University Press, New York, (2013)

6. D. Kesuma, Siswandono, B.T. Purwanto and M. Rudyanto, Journal Chinese Pharmaceutical Science, 29(2), 123(2020), DOI: 10.5246/jcps.2020.02.010

7. A.R. McCarthy, L. Pirrie, J.J. Hollick, S. Ronseaux, J.Campbell, M. Higgins, O.D.Staples, F. Tran, A.M.Z. Slawin, S.Lain and N.J.Westwodd, Bioorganic \& Medicinal Chemistry, 20,1779(2012), DOI:10.1016/j.bmc.2012.01.001

8. T. Widiandani, S. Siswandono, E. Meiyanto, M. Ika, BT. Purwanto and S. Hardjono, Tropical Journal of Pharmaceutical Research, 17(8), 1607(2018), DOI:10.4314/tjpr.v17i8.20

9. D. Abraham, Burger's Medicinal Chemistry and Drug Discovery $6^{\text {th }}$ ed Volume 1: Drug Discovery, John Wiley and Sons, New York, (2003)

10. A.L. Nasyanka, S. Siswandono and S. Hardjono, Thai Journal Pharmaceutical Sciences, 41(3), 99(2017)

11. S. Siswandono, Kimia Medisinal 1, Airlangga University Press, Surabaya, (2016)

12. J. Clayden, N. Greeves, S. Warren and P. Wothers, Organic Chemistry $2^{\text {nd }}$ ed, Oxford University Press, New York, (2012)

13. J.M. McMurry, Fundamental of Organic Chemistry $7^{\text {th }}$ ed, Brooks/Cole, Belmont, (2011)

14. D.L. Pavia, G.M. Lampman, G.S. Kriz, R. James and J.R. Vyvyan, Spectroscopy $4^{\text {th }}$ ed, Brooks/Cole, Belmont, (2009)

15. D. Satria, J. Silalahi, G. Haro, S. Ilyas and P.A.Z. Hasibuan, Rasayan Journal Chemistry, 12(2), 803(2019), DOI: $10.31788 /$ RJC.2019.1225180

16. V. Venkataramireddy, M. Shankaraiah, A. Tejeswara Rao, C. Kalyani, M. L.Narasu, R.Varala and A. Jayashree, Rasayan Journal Chemistry, 9(1), 31(2016)

17. http://ccrc.farmasi.ugm.ac.id/wp-content/uploads/03.010.02-uji-sitotoksik-MTT.pdf

18. C. Avendano and J.C. Menendes, Medicinal Chemistry of Anticancer Drugs $2^{\text {nd }}$ ed., Elsevier, Amsterdam, (2015)

19. A. Bendjeddou, T. Abbaz, S. Maache, R. Rehamnia, A. K. Gouasmia, and D. Villemin, Rasayan Journal Chemistry, 9(1), 18(2016)

20. X. Du, Y. Li, Y. L. Xia, S. M. Ai, J. Liang, P. Sang, and S. Q. Liu, International Journal of Molecular Sciences, 17(2), 144(2016), DOI: 10.3390/ijms17020144

21. P. L. Kastritisand A. M. J. J.Bonvin, Journal of Royal Society Interface, 10(20120835), 1(2012), DOI: 10.1098/rsif.2012.0835

[RJC-5694/2020] 